\title{
Meningoencephalitis due to Naegleria fowleri in cattle in southern Brazil
}

\author{
Meningoencefalite por Naegleria fowleri em um bovino no sul do Brasil \\ Luan Cleber Henker ${ }^{1 *}$ (D); Raquel Aparecida Sales da Cruz ${ }^{2}$; Fernando Soares da Silva ${ }^{3}$; David Driemeier ${ }^{1}$; \\ Luciana Sonne ${ }^{1}$; Francisco Alejandro Uzal ${ }^{4}$; Saulo Petinatti Pavarini ${ }^{1}$ \\ ${ }^{1}$ Setor de Patologia Veterinária, Departamento de Patologia Clínica Veterinária, Universidade Federal do Rio Grande do Sul - \\ UFRGS, Porto Alegre, RS, Brasil \\ ${ }^{2}$ Laboratório de Patologia, Instituto de Biociências, Universidade Federal de Mato Grosso do Sul - UFMS, Campo Grande, MS, \\ Brasil \\ ${ }^{3}$ Fundação Universidade Regional de Blumenau - FURB, Blumenau, SC, Brasil \\ ${ }^{4}$ California Animal Health and Food Safety Laboratory System, University of California - UC, San Bernardino, CA, Davis
}

Received December 30, 2018

Accepted March 22, 2019

\begin{abstract}
Naegleria fowleri is a free-living amoeba commonly found in the environment, mainly in fresh water and soil. This protozoon is occasionally involved in cases of fatal central nervous system disease in humans and other animal species. We describe here a case of meningoencephalitis due to Naegleria fowleri in cattle, in southern Brazil. A four-year-old Angus cow presented a clinical history of initial mild neurological signs that progressed to paddling movements, opisthotonus and lateral recumbency after five days. This animal had been kept in an irrigated rice stubble paddock. Grossly, the main lesions consisted of multiple areas of malacia in the right olfactory bulb, piriform lobes, hippocampus, frontal lobe cortex and fornix, along with severe thickening of the mesencephalon and rhombencephalon leptomeninges. Microscopically, severe multifocal necrosuppurative and hemorrhagic meningoencephalitis associated with a large quantity of amoebic trophozoites was present. The latter were confirmed to be Naegleria spp., through immunohistochemistry. Based on the strong congruence with the histopathological data of known cases reported in the literature, a probable association with Naegleria fowleri was established. To our knowledge, this is only the second report of Naegleria fowleri-associated meningoencephalitis in cattle in South America, and it is the first in southern Brazil.
\end{abstract}

Keywords: Amoeba, bovine, central nervous system disease.

\section{Resumo}

Naegleria fowleri é uma ameba de vida livre, comumente encontrada no meio ambiente, principalmente em água doce e no solo. Este protozoário é ocasionalmente associado a casos fatais de doença do sistema nervoso central em seres humanos e espécies animais. No presente trabalho, um caso de meningoencefalite por Naegleria fowleri em um bovino na região sul do Brasil é descrito. Uma vaca Angus, de quatro anos de idade apresentou histórico clínico caracterizado inicialmente por sinais neurológicos leves que progrediram para movimentos de pedalagem, opistótono e decúbito lateral após cinco dias. Este animal era mantido em um piquete em resteva de arroz irrigado. Macroscopicamente, as principais lesóes foram caracterizadas por múltiplas áreas de malacia no bulbo olfatório direito, lobos piriformes, hipocampo, córtex do lobo frontal e no fórnix, bem como acentuado espessamento das leptomeninges do mesencéfalo e rombencéfalo. Microscopicamente, meningoencefalite necrossupurativa e hemorrágica associada à grande número de trofozoítos amebianos foram observadas. Estes foram confirmados como Naegleria spp. através de imuno-histoquímica. Baseado na forte congruência apresentada entre os dados histopatológicos provenientes de casos conhecidos publicados na literatura, uma provável associação com Naegleria fowleri foi estabelecida. O presente trabalho trata-se do segundo relato de meningoencefalite associada à Naegleria fowleri em bovinos na América do Sul e o primeiro na região sul do Brasil.

Palavras-chave: Ameba, bovino, doença do sistema nervoso central. 
Protozoa of the genera Acanthamoeba, Balamuthia and Naegleria are free-living ameboflagellates that are associated with disease in people and animals (SCHUSTER \& VISVESVARA, 2004). Primary amoebic meningoencephalitis (PAM) is a rare entity caused by Naegleria fowleri (Jonckheere et al., 2011). The disease was first described in humans in Australia (FOWLER \& CARTER, 1965), and subsequently in the United States of America (USA) (BUTT, 1966). This condition has been diagnosed mostly in people, and the majority of the cases have been reported in the USA (CDC, 2017). However, it is believed to have remained unreported in developing tropical countries (SIDDIQUI et al., 2016). Rare reports of such infection in animal species, including cattle, are available (LOZANO-ALARCÓN et al., 1997; DAFT et al., 2005; MORALES et al., 2006; PIMENTEL et al., 2012).

Naegleria fowleri causes a highly fatal acute form of necrosuppurative and hemorrhagic meningoencephalitis. The etiological agent is a widely distributed thermophilic free-living amoeba that is frequently found in fresh and hot water (SIDDIQUI et al., 2016). It is believed to reach the brain through the olfactory nerve (MARTINEZ et al., 1973), where it causes a disease that is restricted to the central nervous system, mostly in immunocompetent individuals (SCHUSTER \& VISVESVARA, 2004).

The purpose of the present report was to describe the pathological findings and to infer the epidemiological aspects involved in a case of Naegleria fowleri-associated meningoencephalitis in a cow in southern Brazil.

A four-year-old Angus cow presented a clinical history of aggressiveness and isolation from the herd that progressed to anorexia, depression and ataxia in March 2017. Symptomatic treatment using doxycycline was administered for three days. However, the neurological signs progressed after five days to paddling movements, opisthotonus and lateral decubitus. Because of the poor prognosis, the animal was euthanized, and the entire head was shipped to the laboratory. This cow was one of 300 beef cattle that were managed in a cow-calf operation in the municipality of Glorinha, in the southern part of the state of Rio Grande do Sul, Brazil. The animals were kept in flooded pastures of swamp rice grass (Leersia hexandra), in a paddock of irrigated rice stubble.

On gross examination, the leptomeninges covering the brain were seen to present multifocal, severely thickened dark red areas that were mainly located on the ventral surfaces of the mesencephalon and rhombencephalon (Figure 1A). In addition, a soft well-demarcated grayish area of $2.5 \mathrm{~cm}$ in diameter was observed on the right olfactory bulb. Similar areas of softening ranging from 0.5 to $2 \mathrm{~cm}$ in diameter were seen bilaterally in the piriform lobes (Figure 1B), right hippocampus, frontal lobe cortex and fornix.

The whole brain, trigeminal ganglion, carotid rete mirabile and pituitary gland were collected and fixed in 10\% neutral buffered formalin for histopathological evaluation. The tissues were routinely processed for production of hematoxylin and eosin (HE) sections of thickness 3-5 $\mu \mathrm{m}$. Selected sections were also processed for immunohistochemistry (IHC), to search for Acanthamoeba spp., Balamuthia spp. and Naegleria spp., as previously described (DAFT et al., 2005). Briefly, brain sections were treated with pepsin and horse serum for antigen retrieval and blocking, respectively, before polyclonal anti-Balamuthia spp.,
Acanthamoeba spp. and Naegleria spp. rabbit antibodies were applied. This was followed by application of the avidin-biotin-peroxidase technique (Vector Laboratories, Inc., Burlingame, CA, USA) and use of 3-amino-9-ethylcarbazole (Dako Corporation, Carpinteria, CA, USA). Sections known to contain the abovementioned amoebae were used as positive controls. Brain from normal cattle was used as a negative control. An additional negative control consisted of identical sections from the case reported here, processed with normal rabbit serum as primary antibody.

Microscopically, multifocal areas of liquefactive necrosis were observed. This affected both the white and grey matter in the right olfactory bulb, frontal brain cortex, thalamus, mesencephalon, piriform lobes and hippocampus. Predominantly on the periphery of the necrotic areas, there was a severe inflammatory infiltrate of viable and degenerate neutrophils, and fewer foamy macrophages (gitter cells), lymphocytes, plasma cells and eosinophils. A few multinucleated giant cells were also observed. In these areas, the Virchow-Robin spaces were expanded by up to seven layers of lymphocytes, macrophages and plasma cells, which extended to the adjacent neuropil.

A large number of round to oval amoebic trophozoites of 12 to $15 \mu \mathrm{m}$ in diameter were seen within the necrotic areas, around and within blood vessels, both in the wall and in the lumen, frequently forming clusters. These amoebae had abundant pale eosinophilic and granular cytoplasm, eccentric nuclei that measured on average 3 to $4 \mu \mathrm{m}$ in diameter and had a single 1 to $2 \mu \mathrm{m}$ hyperchromatic karyosome (Figure $1 \mathrm{C}$ ). The nuclei were surrounded by a clear halo. In addition, multifocally, severe fibrinoid necrosis and hyalinization of blood vessel walls, characterized by accumulation of amorphous proteinaceous material and inflammatory infiltrate of neutrophils, was observed. The necrotic vessels frequently showed thrombosis.

In the cerebellum, the leptomeninges and Virchow-Robins spaces were diffusely and severely expanded by a similar inflammatory infiltrate. In addition, multifocal areas of severe hemorrhage were present in the neuropil, and multifocal moderate areas of gliosis were observed in the cerebellum and in the brainstem. The trigeminal ganglion and nerve showed multifocal areas of moderate infiltration of macrophages, lymphocytes and plasma cells. The carotid rete mirabile and the pituitary gland did not show any significant histopathological changes. The amoebae stained positively for Naegleria spp. through IHC (Figure 1D). Immunostaining for Acanthamoeba spp. and Balamuthia spp. was negative.

The diagnosis of meningoencephalitis due to Naegleria spp. was based on the clinical history and the gross, histological and immunohistochemical findings. Based on the strong congruence with the histopathological data of known cases reported in the literature, a probable association with Naegleria fowleri was established. Only a few case descriptions of spontaneously occurring $N$. fowleri associated with meningoencephalitis have been reported in animal species. The first case was documented in a South American tapir living in a zoo in Arizona, USA (LOZANO-ALARCÓN et al., 1997). Subsequent cases were diagnosed in cattle in the USA (DAFT et al., 2005), Costa Rica (MORALES et al., 2006), Algeria (BENTERKI et al., 2016) and the northeastern region of Brazil (PIMENTEL et al., 2012), and in sheep in Algeria (BENTERKI et al., 2016). In addition, experimentally induced 


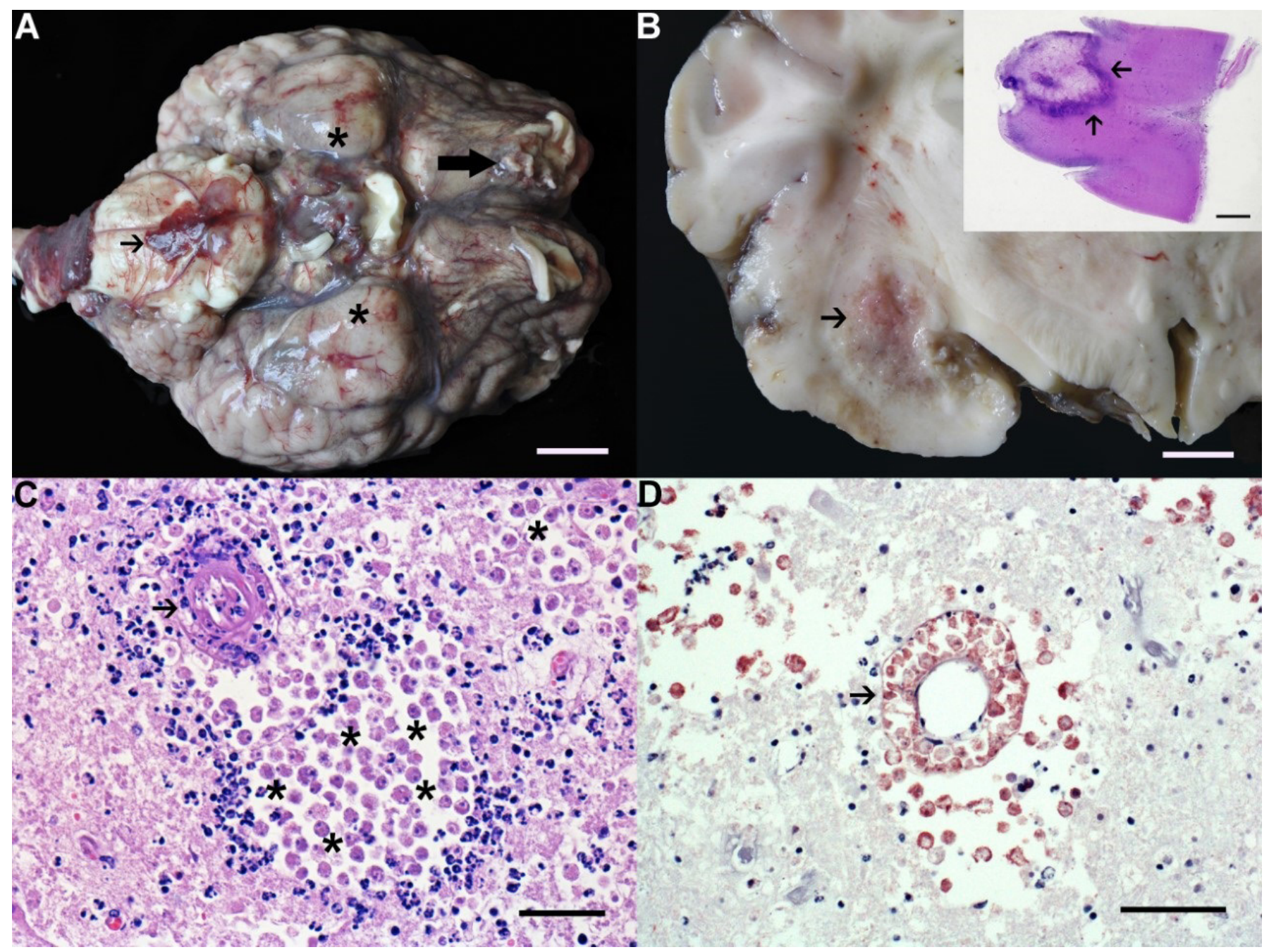

Figure 1. (A) Meningoencephalitis due to Naegleria fowleri in a cow. (A) Gross appearance of ventral surface of encephalon. The brainstem leptomeninges are dark red and present marked thickening. Well-demarcated, slightly yellow areas are seen on the right olfactory bulb and bilaterally in the piriform lobes. Bar $=2 \mathrm{~cm}$; (B) Cross-section through the piriform lobe showing a focal, irregular, red to tan, $1.5 \mathrm{~cm}$ malacic area, which has partially effaced the white-gray junction. Bar $=1 \mathrm{~cm}$. Inset: subgross appearance of the lesion. There is a well-demarcated and pale area of malacia, surrounded by a halo of basophilic cellular debris. Bar $=0.5 \mathrm{~cm}(\mathbf{C})$; A large number of amoebic trophozoites $(N$. fowleri $)$ are observed in perivascular areas, associated with inflammatory infiltrate of neutrophils and fibrinoid degeneration of blood vessel walls. HE, bar $=70 \mu \mathrm{m}$; (D) Strong positive immunostaining for $N$. fowleri. Amoebae are seen distending the wall of a blood vessel, and scattered in the adjacent neuropil. IHC, bar $=110 \mu \mathrm{m}$.

infections have been reported in rats (CARTER, 1970) and sheep (YOUNG et al., 1980). To our knowledge, this is only the second description of this disease affecting cattle in South America, and it is the first in the southern region of Brazil.

Previous reports of $N$. fowleri infection in cattle have suggested that the drinking water was the source of infection, even though amoebae were not detected in the environment on those occasions (DAFT et al., 2005). Even though amoebae were not searched in the environment in the present study, it is possible to infer that the epidemiological characteristics present on the farm where this case occurred, such as the use of pastures in seasonally flooded areas, a common practice in this part of the country, may have favored the occurrence of the disease. This grazing area is annually cultivated with irrigated rice over the summer. After the harvest, cattle are commonly allowed to graze on the area of the rice stubble because it quickly becomes infested with exuberant growth of swamp rice grass (Leersia hexandra), a perennial grass weed that is known for its high tolerance of waterlogging. In addition, this clinical case was registered in March, which is the last month of summer in the southern hemisphere, when maximum temperatures during the day frequently exceed $30^{\circ} \mathrm{C}$ in this area of the country (INMET, 2017). Under these climatic conditions, stagnant water present in the flooded areas of pasture certainly can reach very high temperatures, hence providing a suitable medium for $N$. fowleri proliferation and spreading.

The gross lesions were consistent with previous reports on animals (MORALES et al., 2006; LOZANO-ALARCÓN et al., 1997) and humans (MARTINEZ \& VISVESVARA, 1997). After invading the nasal epithelium, $N$. fowleri is believed to reach the brain through the olfactory nerve, thus causing initial damage 
to the rhinencephalon (MARTINEZ et al., 1973). The lesion is frequently seen as an area of encephalic softening located in the olfactory bulb and adjacent tissue, and it is most commonly unilateral (DAFT et al., 2005), such as in the case described here. The amoebae are believed to spread in the central nervous system through the fluid in the subarachnoid space and through the ventricular system (MARTINEZ \& VISVESVARA, 1997). Therefore, as observed in this case, the lesions tend to be superficial and are commonly seen in various parts of the encephalon (DAFT et al., 2005), which may explain the severity of clinical signs. Meningitis is also a common finding and, as in the present case, it has been observed more frequently in the rhombencephalon (PIMENTEL et al., 2012).

Microscopic changes were characterized by severe lesions affecting blood vessels, including vasculitis and thrombosis, which in the present case seemed to be induced by direct damage caused by the amoebae. Such vascular lesions likely preceded the necrotic changes, since the latter were thought to be the result of infarction, along with direct tissue damage induced by the parasites. Histological visualization of amoebic trophozoites can be challenging, since oftentimes these parasitic structures may resemble foamy macrophages immersed in areas of necrosis and suppurative inflammation (DAFT et al., 2005). Thus, immunohistochemistry is crucial for establishing the diagnosis. Even though several Naegleria species are known, the only agent that has been associated with spontaneous disease in humans and animals is $N$. fowleri, reinforcing the diagnosis in the present case (DE JONCKHEERE, 2011).

Clinical differential diagnoses for $N$. fowleri infection should include toxic, parasitic, bacterial and viral agents affecting the central nervous system of cattle, which in southern Brazil includes rabies virus infection, polioencephalomalacia, cerebral babesiosis and listeriosis. Other etiological agents of amoebic meningoencephalitis in animals should be taken into consideration as possible differential diagnoses, such as Acanthamoeba sp. and Balamuthia mandrillaris (SCHUSTER \& VISVESVARA, 2004), which in the present case were ruled out through negative immunohistochemical staining.

In conclusion, even though occurrences of $N$. fowleri meningoencephalitis are rare, this should be included as a differential diagnosis of neurological disease in cattle in southern Brazil. In addition, grazing on pastures located in flooded areas, which is a frequent practice in this part of the country, may play an important role in the epidemiology of the disease.

\section{Acknowledgements}

The authors thank Coordenação de Aperfeiçoamento de Pessoal de Nível Superior (Capes) and Conselho Nacional de Desenvolvimento Científico e Tecnológico (CNPq) for the schoolarships and financial support provided for the development of the present study.

\section{References}

Benterki MS, Ayachi A, Bennoune O, Régoudis E, Pélandakis M. Meningoencephalitis due to the amoeboflagellate Naegleria fowleri in ruminants in Algeria. Parasite 2016; 23: 11. http://dx.doi.org/10.1051/ parasite/2016011. PMid:26979770.
Butt CG. Primary amebic meningoencephalitis. N Engl J Med 1966; 274(26): 1473-1476. http://dx.doi.org/10.1056/NEJM196606302742605. PMid:5939846.

Carter RF. Description of a Naegleria sp. isolated from two cases of primary amoebic meningoencephalitis, and the experimental pathological changes induced by it. J Pathol 1970; 100(4): 217-244. http://dx.doi. org/10.1002/path.1711000402. PMid:4989229.

Center for Disease Control and Prevention - CDC. Parasites - Naegleria fowleri_Primary Amebic Meningoencephalitis (PAM) - Amebic Encephalitis [online]. 2017 [cited 2017 Nov 18]. Available from: https://www.cdc. gov/parasites/naegleria/general.html

Daft BM, Visvesvara GS, Read DH, Kinde H, Uzal FA, Manzer MD. Seasonal meningoencephalitis in Holstein cattle caused by Naegleria fowleri. J Vet Diagn Invest 2005; 17(6): 605-609. http://dx.doi. org/10.1177/104063870501700617. PMid:16475525.

De Jonckheere JF. Origin and evolution of the worldwide distributed pathogenic amoeboflagellate Naegleria fowleri. Infect Genet Evol 2011; 11(7): 1520-1528. http://dx.doi.org/10.1016/j.meegid.2011.07.023. PMid:21843657.

Fowler M, Carter RF. Acute pyogenic meningitis probably due to Acanthamoeba sp.: a preliminary report. Br Med J 1965; 2(5464): 734742, 740-742. PMID: 5825411.

Instituto Nacional de Metereologia - INMET [online]. 2017 [cited 2017 Nov 20]. Available from: http://www.inmet.gov.br/portal/

Lozano-Alarcón F, Bradley GA, Houser BS, Visvesvara GS. Primary amebic meningoencephalitis due to Naegleria fowleri in a South American tapir. Vet Pathol 1997; 34(3): 239-243. http://dx.doi. org/10.1177/030098589703400312. PMid:9163883.

Martinez AJ, Duma RJ, Nelson EC, Moretta FL. Experimental Naegleria meningoencephalitis in mice. Penetration of the olfactory mucosal epithelium by Naegleria and pathologic changes produced: a light and electron microscope study. Lab Invest 1973; 29(2): 121-133. PMid:4724845.

Martinez AJ, Visvesvara GS. Free-living, amphizoic and opportunistic amebas. Brain Pathol 1997; 7(1): 583-598. http://dx.doi.org/10.1111/j.1750-3639.1997. tb01076.x. PMid:9034567.

Morales JA, Chaves AJ, Visvesvara GS, Dubey JP. Naegleria fowleriassociated encephalitis in a cow from Costa Rica. Vet Parasitol 2006; 139(1-3): 221-223. http://dx.doi.org/10.1016/j.vetpar.2006.03.011. PMid:16638625.

Pimentel LA, Dantas AFM, Uzal F, Riet-Correa F. Meningoencephalitis caused by Naegleria fowleri in cattle of northeast Brazil. Res Vet Sci 2012; 93(2): 811-812. http://dx.doi.org/10.1016/j.rvsc.2012.01.002. PMid:22285703.

Schuster FL, Visvesvara GS. Free-living amoebae as opportunistic and non-opportunistic pathogens of humans and animals. Int J Parasitol 2004; 34(9): 1001-1027. http://dx.doi.org/10.1016/j.ijpara.2004.06.004. PMid:15313128.

Siddiqui R, Ali IKM, Cope JR, Khan NA. Biology and pathogenesis of Naegleria fowleri. Acta Trop 2016; 164: 375-394. http://dx.doi. org/10.1016/j.actatropica.2016.09.009. PMid:27616699.

Young MD, Willaert E, Neal FC, Simpson CF, Stevens AR. Experimental infection of sheep with Naegleria fowleri of human origin. Am J Trop Med Hyg 1980; 29(3): 476-477. http://dx.doi.org/10.4269/ajtmh.1980.29.476. PMid:7386727. 